\title{
ANCIENT MAYA STONE TOOLS AND RITUAL USE OF DEEP VALLEY ROCKSHELTER, BELIZE
}

\author{
W. James Stemp ${ }^{1}$, Gabriel D. Wrobel ${ }^{2}$, Jessica Haley ${ }^{3}$, and Jaime J. Awe
}

\begin{abstract}
This paper discusses the technological and microscopic use-wear analyses of the chert debitage excavated from Deep Valley Rockshelter. This rockshelter, located in the Caves Branch River Valley of central Belize, was primarily used by the ancient Maya from the Late Preclassic to Terminal Classic periods (AD 80-950) and may demonstrate a pattern of rockshelter usage by the Classic period Maya. To test whether such a pattern exists, lithic data from Caves Branch Rockshelter and other rockshelters in Belize, specifically those in the Sibun Valley and the Ek Xux Valley, are compared. Interpretations are complicated, however, by the severe mixing of deposits, which makes segregating the lithic artifacts into different reduction or use events nearly impossible. Moreover, this mixing severely hampers reconstructions of diachronic change in stone-tool use in the rockshelter. While acknowledging these limitations, our analysis suggests that the lithics in the rockshelter are primarily the result of reduction and use-related activities that originally occurred at other nearby surface sites rather than in the rockshelter itself. Consequently, the chipped-stone artifacts recovered from this rockshelter most likely result from secondary deposition of debitage for ritual purposes and represent accumulation over many years. We suspect this type of secondary deposition of debitage was also occurring at other rockshelters in Belize, based on comparisons to the chipped stone assemblages from these locations. We cannot discount the possibility that some stone tool production and use may have originally occurred in Deep Valley Rockshelter, but support for this is minimal.
\end{abstract}

\section{INTRODUCTION}

The use of caves has long fascinated archaeologists working in Belize (see McNatt, 1996). That they are connected to ritual activity is considered a certainty (e.g., Brady and Prufer, 2005; Prufer and Brady, 2005). However, the ritual activities that occurred within caves and rockshelters are believed to have varied and likely involved different types of ritual specialists (Prufer, 2002, p. 43-51, 2005; Vogt and Stuart, 2005). As a further contribution to the unfolding story of how the ancient Maya used these spaces, this paper presents the results of the technological and microscopic use-wear analyses of the chipped-stone artifacts from Deep Valley Rockshelter (DVR1). To provide a larger framework for understanding chipped-stone tools in caves and rockshelters, the DVR1 lithic data are compared to those from other rockshelters and caves used by the ancient Maya. The possible uses of chipped-stone tools in DVR1 are also considered in relation to ethnographic and ethnohistoric evidence.

\section{Maya Cave Rituals and Ritual Objects}

Our understanding of the ideological significance of caves to the ancient Maya is based on archaeological, ethnohistoric, and ethnographic information. Caves and the natural water-filled sinkholes called cenotes were places where human sacrifices, often children, were made, where the Maya buried their dead, and where the living went to make offerings of various types to gain the favor of their ancestors and supernatural beings, such as earth and rain gods (Brady, 1989; Gibbs, 1998; Ishihara, 2008; Moyes et al., 2009; Prufer, 2002, 2005; Tozzer, 1941; Vogt and Stuart, 2005). Many objects have been used as offerings by past and present-day Maya, including animals, blood, ceramics, wood, candles, incense, maize, cacao, shells, crystals, pebbles, obsidian blades, and chipped-chert flakes and implements (e.g., Awe et al., 2005; Bassie-Sweet, 1991; Brady and Prufer, 1999; Halperin et al., 2003; Morehart, 2005; Moyes et al., 2009; Prufer, 2002, 2005; Prufer and Hurst, 2007; Prufer et al., 2003). Like their modern descendants, the ancient Maya associated chert with lightning (Freidel et al., 1993, p. 200), and given that many underworld rituals focused on rain, fertility, and sustenance, the deposition of chert debitage in caves and rockshelters may very likely have been related to this ideology. With regard to chert flakes, some contemporary Maya will collect debitage for use as ritual objects during divination (Brown 2000, p. 330). Brady (1989, p. 319) mentions that the Chorti Maya kept unshaped chert pieces

\footnotetext{
${ }^{1}$ Dept. of Sociology, Anthropology and Criminology, Keene State College, 229 Main St., Keene, NH, 03435-3400, USA jstemp@keene.edu

${ }^{2}$ Dept. of Anthropology, Michigan State University, 655 Auditorium Drive, East Lansing, MI, 48824, USA

${ }^{3}$ Loyola Intensive English Program, 6363 St. Charles Avenue, Campus Box 205, New Orleans, LA 70118, USA

${ }^{4}$ Dept. of Anthropology, Northern Arizona University, 575 E. Pine Kooll Dr. Flaystaff, AZ, 86011, USA
} 


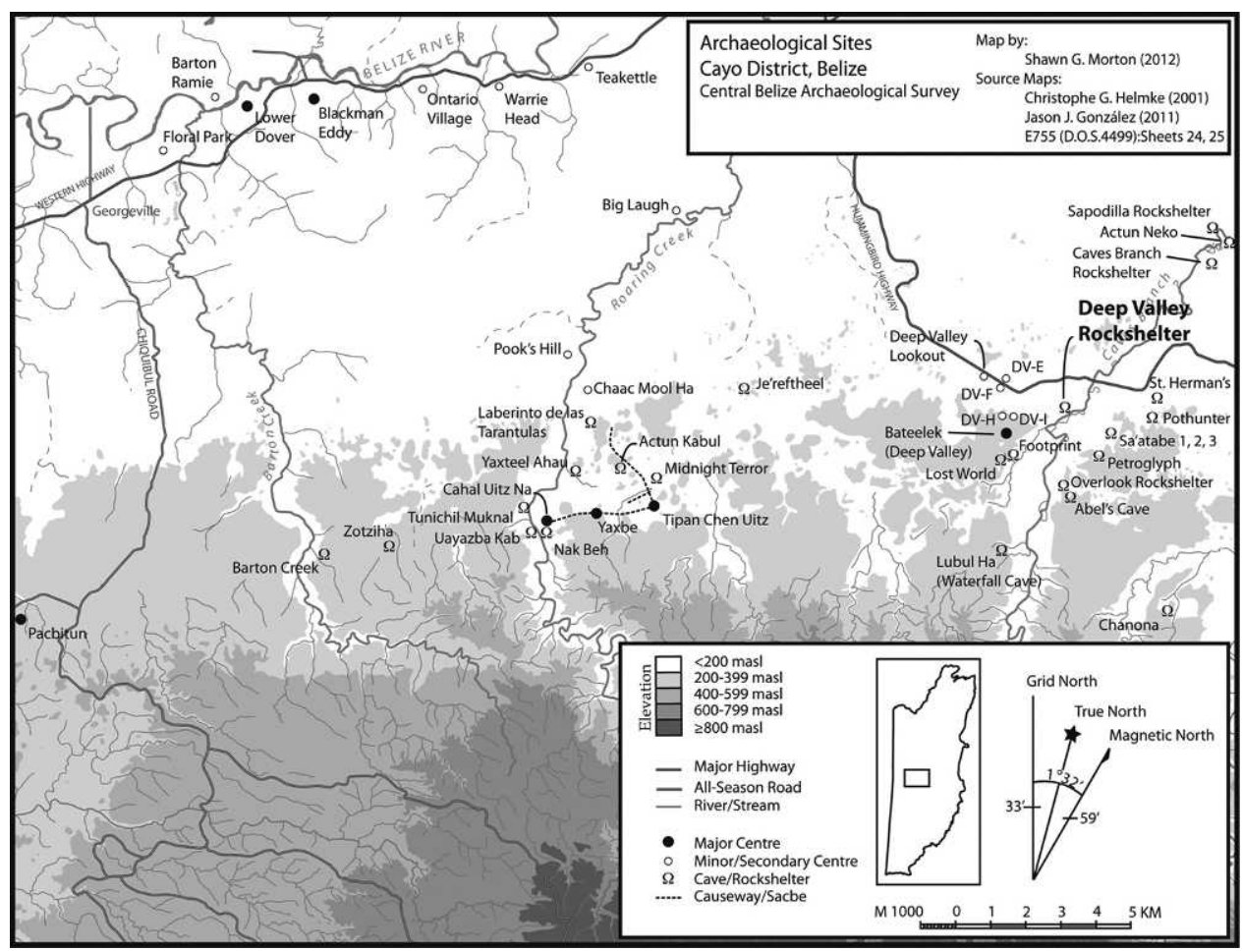

Figure 1. Locations of Deep Valley Rockshelter and Caves Branch Rockshelter in the Cayo District of Western Belize.

on altars and that chert is associated with the rain gods who are believed to dwell in caves (see Wisdom, 1940, p. 382). Ethnographic evidence also indicates that jute, the freshwater gastropod Pachychilus sp., was included in rituals (Healy et al., 1990, p. 171). The Q'eqchi' Maya transported the shells of consumed jute to caves, where they would be deposited to thank the Earth goddess (Halperin et al., 2003). The Lacandon Maya of Naha are also reported to have consumed jute daily during periods of ritual seclusion (Brady 1989, p. 381).

\section{Deep Valley Rockshelter}

Deep Valley Rockshelter is an open rockshelter with a western exposure that is approximately $58 \mathrm{~m}$ long by $15 \mathrm{~m}$ deep. The site was encountered during reconnaissance in the Cayo District, Belize (Fig. 1), in the area near the Caves Branch Rockshelter in 2006 and excavated over two fourweek periods in 2006 and 2007. It is located $2 \mathrm{~km}$ southwest of $\mathrm{CBR}$, in a limestone cliff face overlooking the Caves Branch River. The rockshelter has an $18 \mathrm{~m}$ high ceiling and relatively shallow overhang (Fig. 2). At the southeastern end of the rockshelter, there are two short, narrow passages leading into a cave approximately $15 \mathrm{~m}$ deep.

Investigations at DVR1 included base-line mapping, topographic mapping, and test-pitting. Throughout the site, artifacts littered the surface, and they were also found in large quantities in a wall crevice near its center. Four operations were established at DVR1, each placed strategically to take advantage of visible surface artifacts or notable morphological features (Fig. 3). The artifacts discussed in this study came from two of these, Operations $1 \mathrm{~A}$ and $1 \mathrm{~B}$, located in the center of the rockshelter. The other two operations, $1 \mathrm{C}$ and $1 \mathrm{D}$, contained no lithic artifacts and very little cultural material in general. Operation 1A measured 2 by 2 meters and was terminated at $80 \mathrm{~cm}$ below surface, prior to reaching sterile soil, because of time issues. Operation 1B measured 1 by 2 meters and was terminated at $170 \mathrm{~cm}$ upon reaching sterile soil. All soil was screened through $1 / 8$ inch $(3.12 \mathrm{~mm})$ mesh. Within the units, artifacts were surprisingly dense throughout; thousands of ceramic sherds and jute shells were collected. Several carved-shell beads, polished jade pieces, and fishing weights were also found (Hardy, 2009).

During excavations, we were generally unable to recognize any natural or cultural stratigraphy in the form of distinct variations in the soil or other features. All soil in the excavation units appeared to be relatively consistent in its grayish-brown color and silty texture. In Operation 1B, this relatively uniform cultural layer ended directly over the natural cave floor, which was composed of stone and a red, sterile matrix of decomposing limestone. As a result, we were unable to accurately group artifacts within temporally distinct lots for comparison. A lack of evident stratigraphy has been noted at other rockshelter sites in Mexico (Rissolo, 2003) and Belize (Hardy, 2009; Michael and Burbank, 2013; Prufer, 2002; Wrobel, 2008; Wrobel and Shelton, 2011; Wrobel and Tyler, 2006; Wrobel et al., 2010; Wrobel et al., 


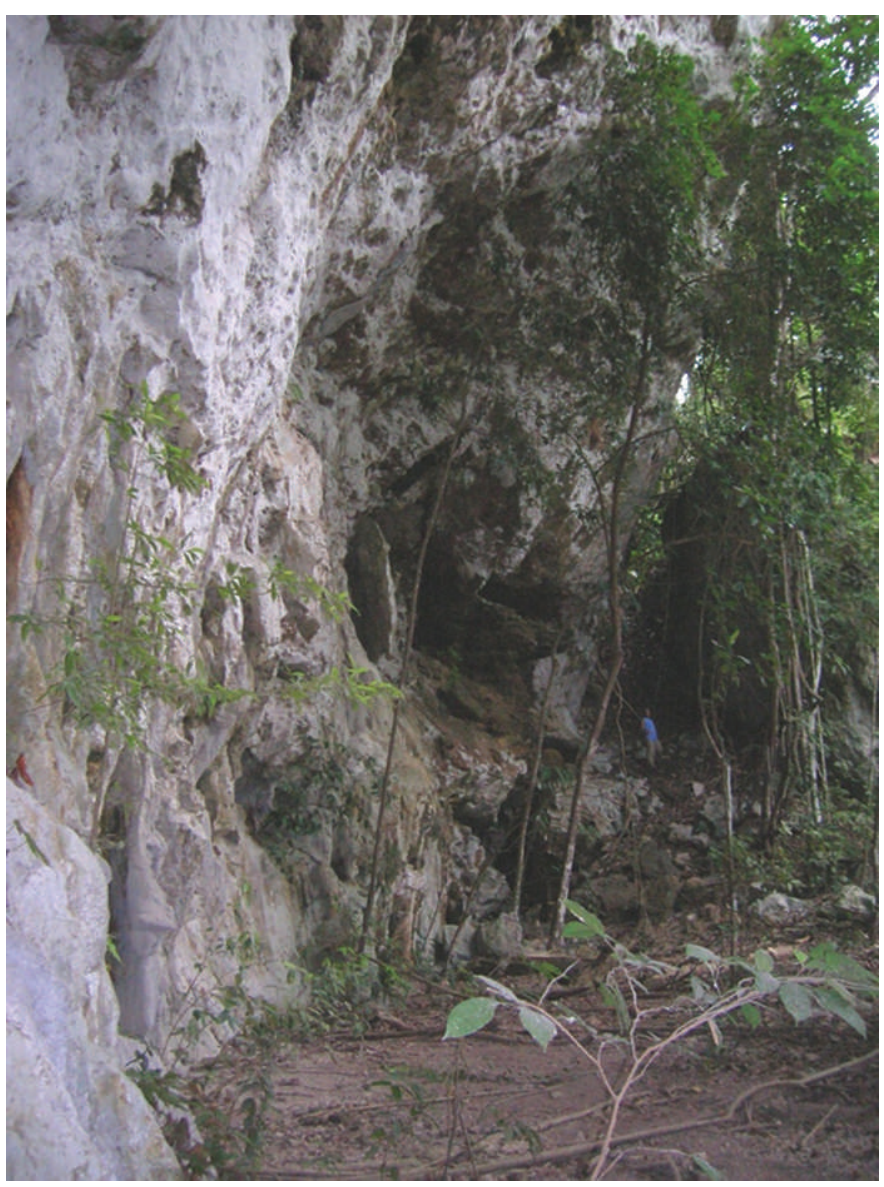

Figure 2. The western exposure of the Deep Valley Rockshelter in a view looking south.

2013), but some excavations at rockshelters in surrounding regions, such as El Gigante in Honduras (Scheffler, 2008) and Guila Naquitz in Oaxaca (Flannery, 1986), have shown a clear stratigraphy corresponding to specific events. In an effort to get some sense of change over time in the activities at our site, we collected artifacts from arbitrary $20 \mathrm{~cm}$ levels, which was the usual strategy in the excavation of the sites mentioned above that lacked visible stratigraphy.

In the absence of any radiocarbon dates for DVR1, diagnostic ceramics categorized using Gifford's (1976) typevariety system provide the best evidence for determining the period of utilization. The sherds comprised a wide variety of finishes, including plain, painted, appliquéd, and polychrome, but unfortunately analysis identified relatively few diagnostic pieces. Among typed specimens, dates spanned the Late Preclassic through the Terminal Classic (AD 80 950), which is consistent with an informal evaluation of the rockshelter's surface deposits. Within the excavations, the most commonly represented periods were the Protoclassic and Early Classic. Late and Terminal Classic pottery appears to be limited to the surface and the topmost $20 \mathrm{~cm}$ level, with no examples identified deeper in the excavations. However, ceramics dating to between the Late

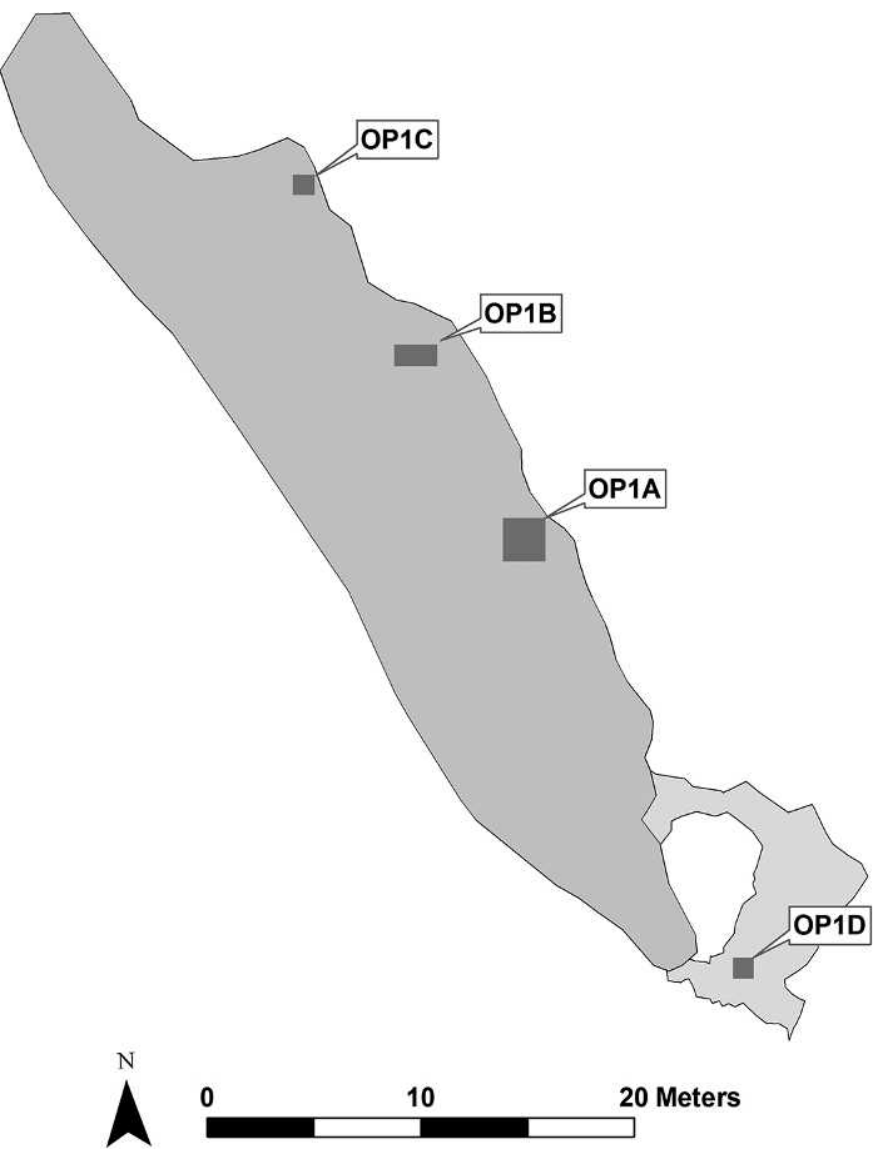

Figure 3. Map of Deep Valley Rockshelter showing excavation units. OP1A and OP1B are the sources of the lithic artifacts discussed in the paper.

Preclassic and Early Classic were found at all depths. This mixing of ceramics throughout the matrix makes evaluation of the site's history difficult. However, other clues do provide some insight. For instance, all recovered ceramics appear to have been deposited as individual sherds, with few refits and no whole vessels evident. This kind of variation in ceramic sherds is fairly typical at rockshelters in the area (Hardy, 2009; Shelton, 2013).

There are a couple of possible explanations for the type of soil and artifact commingling described above. At other sites, such as the Caves Branch Rockshelter, this was easily attributable to extensive mixing of grave fill during the burials of hundreds of individuals throughout the nearly thousand-year span of site use (Wrobel et al., 2007). Although one of the DVR1 units was placed specifically around human bone fragments found on the surface, excavations revealed very few human remains, prohibiting interpretations of funerary use. The paucity of human bone in DVR1 clearly was not due to taphonomic issues, because human and faunal remains were generally well preserved. Therefore, mixing in the DVR1 rockshelter occurred by some other bioturbation mechanism, possibly water or burrowing animals. 
Table 1. Non-obsidian artifacts from Deep Valley Rockshelter.

\begin{tabular}{|c|c|c|c|c|c|c|}
\hline & & River Cobble & & River Cobble & & \\
\hline Tool Type & Chert & Chert & Chalcedony & Chalcedony & Limestone & Quartzite \\
\hline & \multicolumn{6}{|c|}{ Formal Tools } \\
\hline Blades & 1 & $\ldots$ & $\ldots$ & $\ldots$ & $\ldots$ & $\ldots$ \\
\hline Large bifaces & 2 & $\ldots$ & $\ldots$ & $\ldots$ & $\ldots$ & $\ldots$ \\
\hline \multirow[t]{2}{*}{ Miscellaneous thin bifaces } & 1 & $\ldots$ & $\ldots$ & $\ldots$ & $\ldots$ & $\ldots$ \\
\hline & \multicolumn{6}{|c|}{ Informal Tools/Debitage } \\
\hline Flakes (cortical) & 76 & 6 & $\ldots$ & 1 & 4 & $\ldots$ \\
\hline Flakes (non-cortical) & 102 & $\ldots$ & $\ldots$ & $\ldots$ & 1 & 3 \\
\hline Bifacial thinning flakes (non-cortical) & 1 & $\ldots$ & 1 & $\ldots$ & $\ldots$ & $\ldots$ \\
\hline Retouched macroflakes (cortical) & 1 & $\ldots$ & $\ldots$ & $\ldots$ & $\ldots$ & $\ldots$ \\
\hline Retouched flakes (cortical) & $\ldots$ & 1 & $\cdots$ & $\cdots$ & $\cdots$ & $\cdots$ \\
\hline Flake-blades (cortical) & 1 & $\ldots$ & $\ldots$ & $\ldots$ & $\ldots$ & $\ldots$ \\
\hline Flake-blades (non-cortical) & 4 & $\ldots$ & $\ldots$ & $\ldots$ & $\ldots$ & $\ldots$ \\
\hline Small bifacial edge retouch flakes - & & & & & & \\
\hline $\begin{array}{l}\text { percussion (cortical) } \\
\text { smestl }\end{array}$ & 2 & $\cdots$ & $\cdots$ & $\cdots$ & $\cdots$ & $\cdots$ \\
\hline Small unifacial retouch flakes (non-cortical) & 1 & $\cdots$ & $\cdots$ & $\cdots$ & $\cdots$ & $\cdots$ \\
\hline Simple flake cores & 2 & $\cdots$ & $\cdots$ & $\cdots$ & $\cdots$ & $\cdots$ \\
\hline $\begin{array}{l}\text { Simple flake core fragments } \\
\text { Blocky fragments/shatter }\end{array}$ & 11 & $\cdots$ & $\cdots$ & $\cdots$ & $\cdots$ & $\cdots$ \\
\hline $\begin{array}{l}\text { Blocky tragments/shatter } \\
\text { Heavily burnt fragments (including potlids) }\end{array}$ & $\begin{array}{l}31 \\
14\end{array}$ & $\begin{array}{l}\cdots \\
\cdots\end{array}$ & $\begin{array}{l}\cdots \\
\cdots\end{array}$ & $\begin{array}{l}\cdots \\
\cdots\end{array}$ & $\ldots$ & $\begin{array}{l}\cdots \\
\ldots\end{array}$ \\
\hline Total & 250 & 7 & 1 & 1 & 7 & 3 \\
\hline
\end{tabular}

\section{The Chipped-Stone Assemblage from Deep VALLEy RockSHELTER}

The chipped-stone assemblage consists of 274 artifacts. Most of the artifacts were made from chert ( 257 or $93.8 \%$ ) that was obtained locally in the form of cobbles from nearby creeks or rivers or from nodules and lenses that formed in natural limestone in the area surrounding the rockshelter. Small quantities of other locally available stone include chalcedony ( 2 or $0.7 \%$ ), limestone $(7$ or $2.6 \%$ ), and quartzite ( 3 or $1.1 \%$ ). The only imported stone is obsidian from the Guatemalan highlands (5 or 1.8\%), which was identified based on visual sourcing (see Braswell et al., 2000). This pattern of heavy dependence on local chert sources is also seen in other caves and rockshelters in western and southern Belize (Peterson, 2006; Prufer, 2002; Stemp, 2009; Stemp et al., 2013).

Nearly all of the chipped-stone artifacts are debitage (268 or 97.1\%), defined as "the waste produced by manufacturing processes using reductive technologies" (Moholy-Nagy, 1990, p. 269), including stone flakes and flake fragments of various types, shatter, and exhausted cores (Table 1). Only eight formal tool fragments were recovered. Four are obsidian prismatic blade segments that were punched from prepared cores and were most likely brought into the rockshelter in finished form. This is a pattern observed at other rockshelters and caves in the Maya world, in which there is little evidence for obsidian blade manufacture in the form of obsidian cores, early-stage thick blades, and flake debitage (e.g., Aoyama, 2001; Brady, 1989; Helmke, 2009; Peterson, 2006; Prufer, 2002; Stemp and Awe, 2014; Stemp et al., 2013). Whether the four obsidian blades were used for ritual activities, such as blood-letting or sacrifice (Aoyama, 2001; Stemp, 2009; Stemp and Awe, 2014; Stemp et al., 2013), inside the rockshelter cannot be ascertained.

The other formal tool fragments are made of chert and include part of an oval biface, an oval biface edge flake, the distal end of a thin biface, and a blade segment. No whole formal tools were recovered from the Deep Valley Rockshelter. In southern Belize, Prufer (2002, p. 237, Table 7.1) notes similar patterns at some rockshelters, in which there are either few or no formal chert tools and substantial quantities of debitage. The absence in rockshelters of whole or nearly complete chert tools, specifically large, thin bifaces, which are common in the ritual deposits of other caves (e.g., Brady, 1989; Graham et al., 1980; Helmke, 2009; Pendergast, 1971; Peterson, 2006), suggests the possibility that formal tool deposition in caves differs from that in rockshelters.

The debitage from DVR1 overwhelmingly consists of a variety of both cortical flakes, with some of the original rough, weathered surface of a nodule retained on the dorsal surface of the flake, and non-cortical chert flakes (Fig. 4). Evidence suggests that most reduction was the result of simple flake production using hard-hammer percussion. Both the flake dimensions and the high frequency of cortical and flat striking platforms (89.1\%) support this 


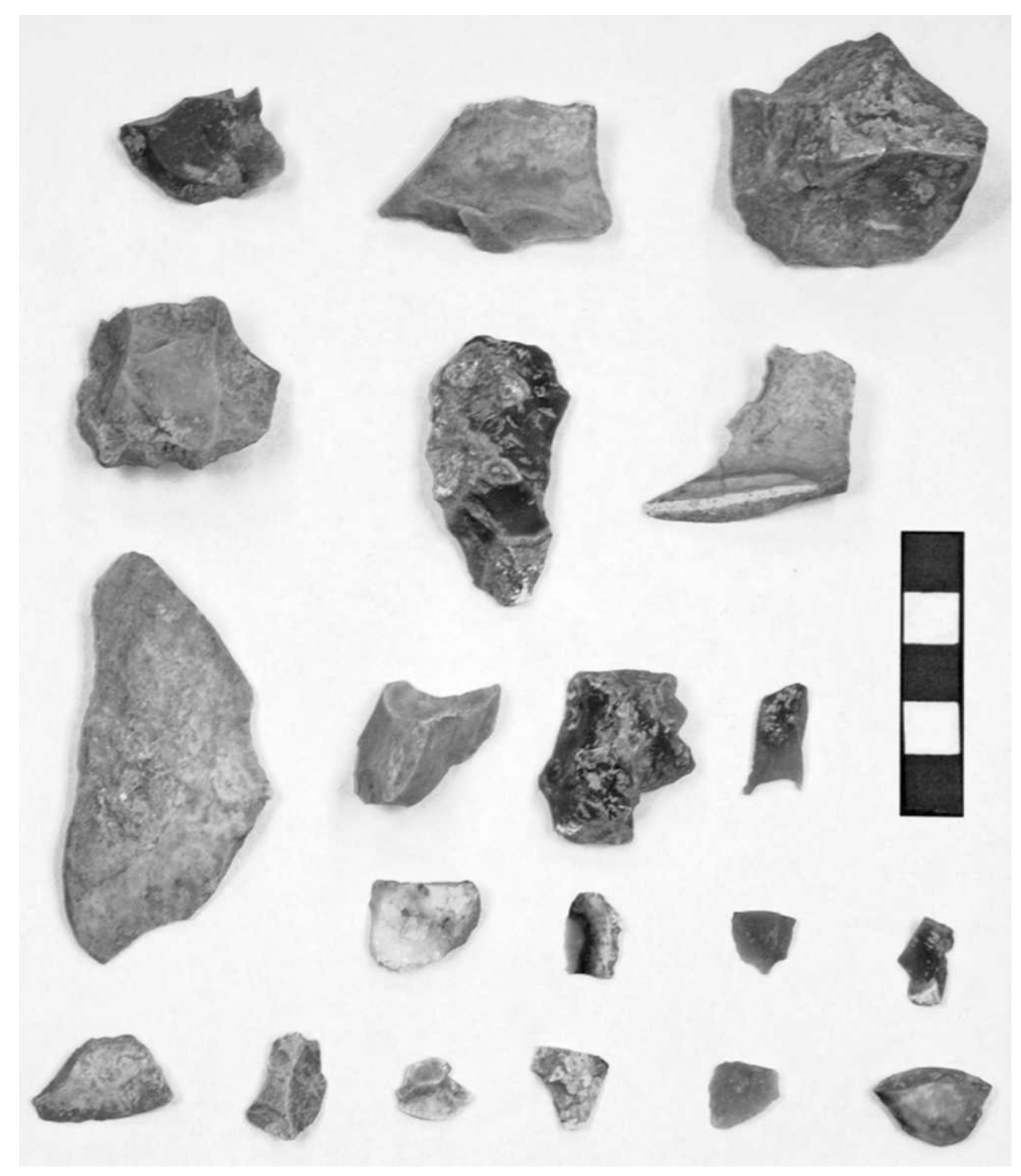

Figure 4. Examples of chert debitage from Deep Valley Rockshelter. The scale is in centimeters.

conclusion. There are only two examples of bifacial thinning flakes resulting from biface manufacture, and two other flakes have lipped platforms that suggest removal from bifaces. The lack of manufacturing failures or biface preforms further suggests that the majority of debitage from DVR1 is not the result of biface production. When the chert debitage from DVR1 is compared to the assemblages from other rockshelters, both similarities and differences are noted. Although Caves Branch Rockshelter and Pine Torch Rockshelter both yielded large quantities of debitage, non-cortical flakes are much more frequent at these locations (Table 2), which would suggest different reduction patterns than those seen at DVR1, if flaking originally occurred in the rockshelters themselves.

Only two pieces $(0.7 \%)$ of microdebitage (flakes measuring less than $3 \mathrm{~mm}$ in maximum dimension, see Hayden and Cannon, 1983) were found in DVR1, which suggests that primary tool production was unlikely in the rockshelter itself (see Behm, 1983; Clark, 1991; Morrow, 1996). Because all excavated soil was screened, we do not believe the very small amount of microdebitage is the result of recovery methods. Unfortunately, the contextual issues noted above render determinations of how much primary tool production versus secondary disposal of debitage occurred in DVR1 extremely difficult (Wilson, 1994; see Moholy-Nagy, 1990). Nevertheless, the lack of manufacturing tools like hammerstones seems to support the interpretation that most, if not all, core reduction originally occurred outside DVR1 (Moholy-Nagy, 1990). Prufer (2002, p. 225) and Stemp et al. (2013) noted the absence of flaking implements and a paucity of cores in the assemblages from Caves Branch Rockshelter and the rockshelters in the Ek Xux Valley.

Another possible indicator of secondary deposition of chert artifacts is the near absence of refits in the assemblage 
Table 2. Percentage of the original rough, weathered surface of a nodule retained on the dorsal surface of local chert and chalcedony flakes from area rockshelters.

\begin{tabular}{lccc}
\hline $\begin{array}{l}\text { Dorsal } \\
\text { Cortex }\end{array}$ & CBR $^{\mathrm{a}}$ & $\begin{array}{c}\text { Pine Torch } \\
\text { Rockshelter }^{\mathrm{b}}\end{array}$ & DVR \\
\hline $0 \%$ & $1420(76.6 \%)$ & $82(75 \%)$ & $102(54.8 \%)$ \\
$1-50 \%$ & $339(18.3 \%)$ & $\ldots$ & $64(34.4 \%)$ \\
$51-99 \%$ & $83(4.5 \%)$ & $\ldots$ & $14(7.5 \%)$ \\
$100 \%$ & $12(0.6 \%)$ & $\ldots$ & $6(3.2 \%)$ \\
Total & 1854 & 110 & 186 \\
\hline
\end{tabular}

a (Stemp et al., 2013).

${ }^{\mathrm{b}}$ (Peterson, 2006, p. 165).

(Andrefsky, 2009; Morrow, 1996). We tried to rearticulate flakes to bifaces and cores, as well as to other flakes that may have been involved in the same reduction process. The attempted refitting of tools and debitage included all chert artifacts from the rockshelter. The artifacts were subdivided into groups based on similarity of color and stone texture. Fifteen such groups, ranging in size from a half dozen to over forty pieces, were created, with an additional catch-all group that consisted of any single flakes or fragments that could not be assigned to another group. Each group was examined individually for refits and then compared to the pieces in the catch-all group. No flakes could be refit to formal tool fragments or flake cores. From only one of the groups, two flakes could be rearticulated, and they each came from different levels in different excavation units. Nevertheless, both the relatively small sample size and the mixing of deposits (Morrow, 1996) cannot be discounted as factors in reducing the number of refits.

\section{Microscopic Use-wear Analysis: Methods AND RESULTS}

Tool use for the lithic artifacts from Deep Valley Rockshelter was determined following a program of microscopic use-wear analysis similar to that used by Stemp (2001; Stemp et al., 2010, 2013) for assemblages from other Maya sites. It involves both the low-power $(40 \times)$ and high-power (100 to $400 \times$ ) microscopic examination of tool surfaces for edge-chipping, striations, and polishes related to human use. Used areas identified on the artifacts were tabulated and categorized following an independent-use-zone [IUZ] system (see Aoyama, 2009). Recognition of motion types and contact material types is primarily based on comparisons with experimentally used tools (Stemp, 2001).

Of the 265 chert, chalcedony, limestone, and quartzite informal tools and debitage recovered, $31(11.7 \%)$ were so badly burnt or heavily patinated that use-wear analysis was not possible. Only $40(17.1 \%)$ of the remaining artifacts possessed some evidence for having been used in the past.
The number of IUZs identified on these artifacts is 47 $(20.1 \%)$. Use-wear analysis indicates that debitage was used for a fairly wide variety of tasks (Table 3). This observation has been made by use-wear analysts who have examined debitage from other Maya sites (e.g., Aoyama, 2009; Lewenstein, 1987; Stemp, 2001; Stemp et al., 2010).

Most of the flakes from DVR1 were used for cutting, slicing, and sawing, which may be due to the generally low edge-angles of these flakes. This is followed in frequency by scraping and planing motions. These are similar to data from Caves Branch Rockshelter, but, unlike CBR, there is no use-wear evidence at DVR1 for adzing/chopping, drilling, incising, or graving (Stemp et al., 2013). In terms of contact materials, most flakes from DVR1 were used to work bone, meat, hide (Figs. 5, 6), and wood, which is similar to results from CBR, but the data from DVR1 demonstrate more contact with bone and hard materials (Fig. 7) and less with wood. There is no evidence for contact with ceramic, shell, or soil on the debitage from DVR1.

Overall, the use of debitage for the completion of many tasks and the kinds of motions and contact materials are consistent with subsistence and other utilitarian, domestic tasks that would be undertaken by the Maya in their daily lives (Lewenstein, 1987; Stemp, 2001; Stemp et al., 2010). Although the high percentage of tools with meat, bone, and hide polish might support some interpretations that ceremonial or ritual butchery or sacrifice of animals occurred in DVR1 (see Sievert, 1992, p. 40-41, Table 4.4), few faunal remains, with the exception of jute shells, were recovered within the rockshelter. This suggests tool use associated with animals may have taken place at locations outside this space, but the meat, hide, and bone polishes on the chert debitage from DVR1 could also be the result of hunting and butchering activities, including some carcass processing, as well as domestic crafting (Lewenstein, 1987; Sievert, 1992, p. 37-38, Table 4.3). The greasy appearance of polish on some of the bone-working tools may indicate contact with cooked bone (Keeley, 1980, p. 44), which would be more closely associated with subsistence activities. Nevertheless, some bones may have been associated with ritual activity (see Kavountzis, 2009; Pohl, 1983), and it is possible small animals, such as rodents, were sacrificed (Aoyama, 2001; Sievert, 1992, p. 89).

Like many caves and rockshelters in the Maya world (e.g., Brady, 1989; Graham et al., 1980; Halperin et al., 2003; Helmke, 2009; MacLeod and Puleston, 1978), dense deposits of jute shells were also recovered from DVR1 (Hardy, 2009). This has been noted at CBR (Bonor and Martínez Klemm, 1995; Wrobel and Tyler, 2006; Hardy, 2009) and in mortuary rockshelters in the Ek Xux Valley (Prufer, 2002) as well. Large quantities of jute shells have been associated with human burials in caves and rockshelters (Ferguson and Gibbs, 1999; Prufer, 2002), possibly to demonstrate a link between death and a watery place like the Underworld or a connection to rain and fertility (Girard, 1962). 
Table 3. Independent use zones showing evidence of various uses on non-obsidian artifacts from Deep Valley Rockshelter.

\begin{tabular}{|c|c|c|c|c|c|c|}
\hline \multirow[b]{3}{*}{ IUZs } & & & \multicolumn{4}{|c|}{ Informal Tools/Debitage } \\
\hline & \multicolumn{2}{|c|}{ Formal Tools ${ }^{\mathrm{a}}$} & \multirow[b]{2}{*}{ Flakes } & \multirow{2}{*}{$\begin{array}{l}\text { Bifacial Thinning Flakes } \\
\text { and Biface Edges }\end{array}$} & \multirow{2}{*}{$\begin{array}{c}\text { Blocky } \\
\text { Fragments }\end{array}$} & \multirow{2}{*}{$\begin{array}{l}\text { Cores and Core } \\
\text { Fragments }\end{array}$} \\
\hline & Thin Bifaces & Blades & & & & \\
\hline \multicolumn{7}{|l|}{ Bone } \\
\hline cut/slice & $\ldots$ & $\cdots$ & 5 & $\cdots$ & $\cdots$ & $\ldots$ \\
\hline pierce & 1 & $\ldots$ & $\ldots$ & $\ldots$ & $\ldots$ & $\ldots$ \\
\hline saw & $\ldots$ & $\ldots$ & 1 & $\ldots$ & $\ldots$ & $\ldots$ \\
\hline scrape/plane & $\ldots$ & $\ldots$ & 2 & $\ldots$ & 1 & 1 \\
\hline \multicolumn{7}{|l|}{ Dry Hide } \\
\hline cut/slice & $\ldots$ & $\ldots$ & 1 & $\ldots$ & $\ldots$ & $\ldots$ \\
\hline scrape/plane & $\ldots$ & $\ldots$ & 2 & $\ldots$ & $\ldots$ & $\ldots$ \\
\hline \multicolumn{7}{|l|}{ Meat/Fresh Hide } \\
\hline cut/slice & $\ldots$ & $\ldots$ & 3 & $\ldots$ & $\ldots$ & $\ldots$ \\
\hline scrape/plane & $\ldots$ & $\ldots$ & $\ldots$ & 1 & $\ldots$ & $\ldots$ \\
\hline \multicolumn{7}{|l|}{ Meat/Bone } \\
\hline cut/slice & $\ldots$ & $\ldots$ & 5 & $\ldots$ & $\ldots$ & $\ldots$ \\
\hline scrape & $\ldots$ & $\cdots$ & 1 & 1 & $\cdots$ & $\cdots$ \\
\hline \multicolumn{7}{|l|}{ Plant } \\
\hline cut/slice & $\cdots$ & $\cdots$ & 1 & $\cdots$ & $\cdots$ & $\cdots$ \\
\hline \multicolumn{7}{|l|}{ Stone } \\
\hline saw & $\ldots$ & $\ldots$ & 1 & $\ldots$ & $\ldots$ & $\ldots$ \\
\hline rub/grind & $\cdots$ & $\cdots$ & 1 & $\ldots$ & $\cdots$ & $\cdots$ \\
\hline \multicolumn{7}{|l|}{ Wood } \\
\hline cut/slice & $\ldots$ & $\ldots$ & 3 & $\ldots$ & $\ldots$ & $\ldots$ \\
\hline saw & $\ldots$ & $\ldots$ & 2 & $\ldots$ & 1 & $\ldots$ \\
\hline scrape/plane & $\ldots$ & $\ldots$ & $\ldots$ & $\ldots$ & 1 & $\ldots$ \\
\hline whittle & $\ldots$ & $\ldots$ & 1 & $\ldots$ & $\ldots$ & $\ldots$ \\
\hline \multicolumn{7}{|l|}{ Soft } \\
\hline cut/slice & $\ldots$ & $\ldots$ & 2 & $\ldots$ & $\ldots$ & $\ldots$ \\
\hline scrape/plane & $\ldots$ & $\ldots$ & $\ldots$ & $\ldots$ & 1 & $\ldots$ \\
\hline \multicolumn{7}{|l|}{ Hard } \\
\hline cut/slice & $\ldots$ & $\ldots$ & 3 & $\ldots$ & $\ldots$ & $\ldots$ \\
\hline saw & $\ldots$ & 1 & 2 & $\ldots$ & $\ldots$ & $\ldots$ \\
\hline \multicolumn{7}{|l|}{ Indeterminate } \\
\hline cut/slice & $\ldots$ & $\ldots$ & 3 & $\ldots$ & $\ldots$ & $\ldots$ \\
\hline indeterminate & $\ldots$ & $\ldots$ & 1 & $\ldots$ & $\ldots$ & $\ldots$ \\
\hline Total & 1 & 1 & 40 & 2 & 4 & 1 \\
\hline
\end{tabular}

${ }^{a}$ The oval biface fragment was unavailable for use-wear analysis.

Both modern and ancient Maya used jute as a source of protein, and some modes of consumption involved the removal of the apex or spire of the shell (Healy et al., 1990). Based on the presence of chert flakes and jute shells at many rockshelters, one suggestion is that chert flakes were used to open the jute shells for consumption. It may be that chert flakes were initially used in jute consumption for subsistence purposes at surface sites and the jute shells were then later ritually deposited in the rockshelters (Halperin et al., 2003; Peterson 2006, p. 210). However, even though most of the jute shells from DVR1 are spire-lopped (Hardy, 2009, p. 127), use-wear analysis does not indicate a connection between stone flakes and jute consumption based on the absence of flakes with evidence for contact with shell.

The reliance on unmodified chert flakes and their usewear patterns suggest similarities to assemblages used in domestic activities at some surface sites in which there is an emphasis on wood (Lewenstein 1987; Stemp 2001; Stemp et al. 2010). It is also possible that use-wear indicating contact 


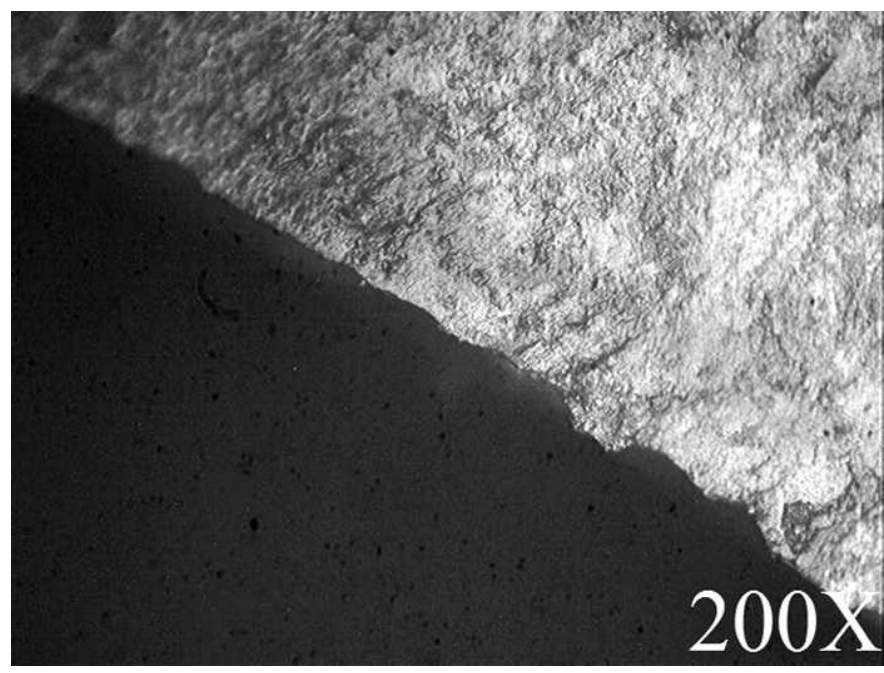

Figure 5. Photomicrograph of a thin-edged chert flake used to cut meat/fresh hide and showing some contact with bone, as indicated by invasive, greasy polish on both lower and higher microtopography with some patches of brighter, micropitted polish; few fine, shallow striations parallel and mildly diagonal to the flake edge; and minimal microchipping on the thinnest portions of the edge (snap fractures).

with wood or plants might be the result of ritual activity or the production of ceremonial items (e.g., Morehart, 2005; Pendergast, 1974; Prufer et al., 2003; Sharon, 2003). Although some of the debitage may have been associated with specialized craft-production involving wood (Aldenderfer, 1991), segregating this evidence from the stone tools

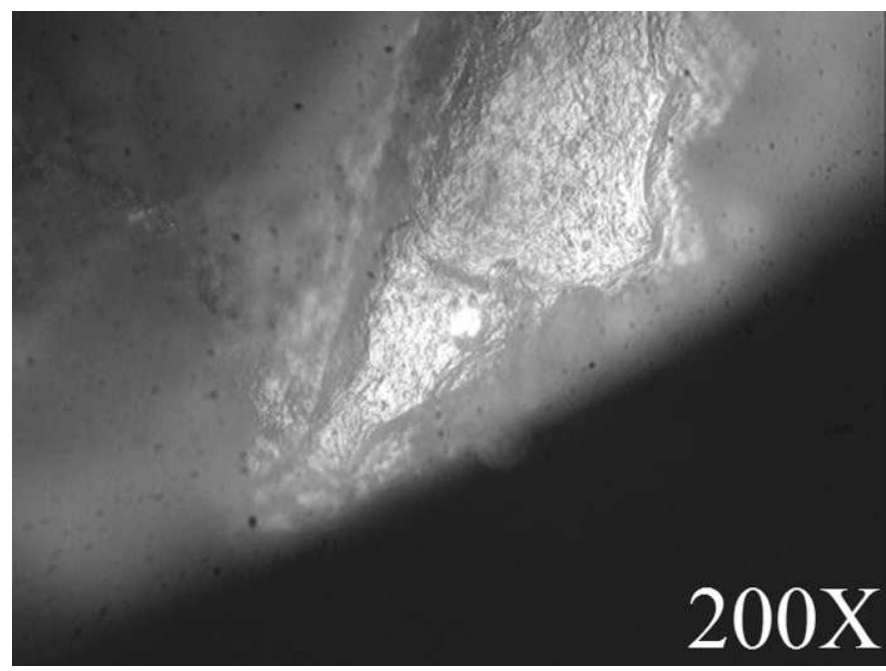

Figure 6. Photomicrograph of a ventral surface of a thickedged chert flake used to scrape bone and meat or fresh hide (defleshing/butchery?), as indicated by greasy, bright, micropitted polish near tool edge, mild edge rounding, and primarily unifacial microflaking of tool edge.

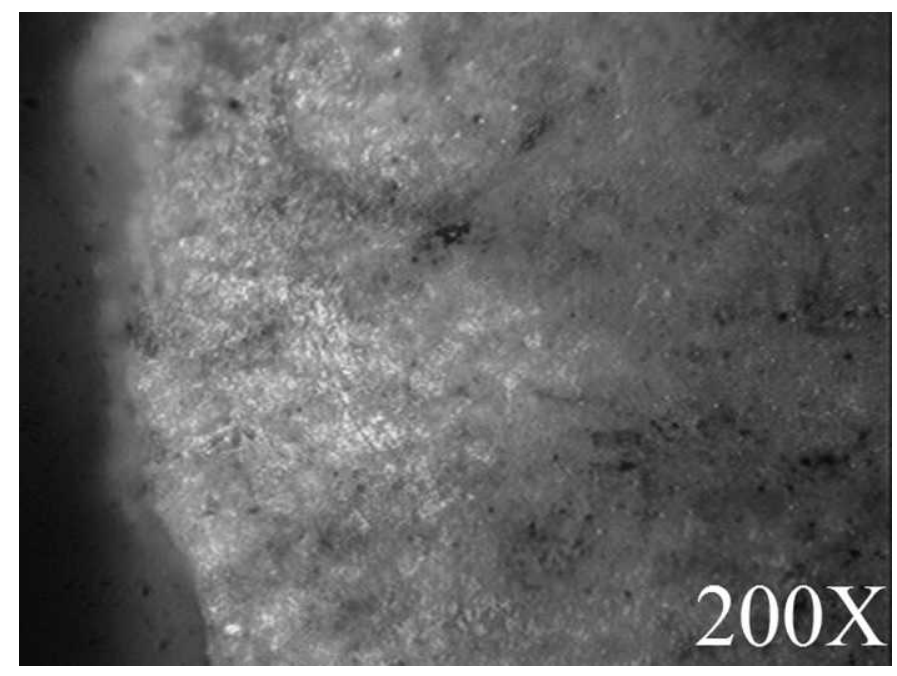

Figure 7. Photomicrograph of a ventral surface of a retouched chert flake used to saw a hard material, as indicated by striations parallel to the edge and a flat, semi-bright polish. Note: Burning and patination of the tool surface complicates use-wear analysis.

that may have been used for domestic activities or ritual is not possible.

\section{Discussion And Conclusion}

The stone tool assemblage from DVR1 is similar in many ways to those from other rockshelters in Belize for which secondary deposition of lithic artifacts for ritual purposes has been proposed (Peterson, 2006; Prufer, 2002; Stemp et al., 2013) and suggests that chert debitage was brought into the rockshelter at different points in time as special deposits (Moholy-Nagy, 1990; see Brown, 2000). Prufer (2002, p. 225) suggests that chert debitage recovered from the rockshelters in the Maya Mountains "may be parts of ceremonial trash (Walker, 1995) carried into the sites. They may also be objects that were collected by ritual specialists and placed into the rockshelters (Brown, 2000)".

Large accumulations of chert and obsidian debitage are also sometimes associated with burials, particularly the tombs of elites or high-status individuals (Moholy-Nagy 1990, p. 271-272, 1997), as demonstrated at surface sites in the Cayo District of Belize (e.g., Chase and Chase 1996; Chiarulli and Barrick, 1997; McAnany and Peterson, 2004) and in a least one cave (Griffith, 1998, p. 59). Dense layers of debitage are believed to represent connections to the Underworld (Hall 1989, p. 308). The layers of stone may also be associated with the rain gods (Wisdom, 1940, p. 383) or lightning (see above). However, the flakes from DVR1 were not recovered as a dense lens in association with any burials. The flakes were scattered throughout the rockshelter and were recovered from multiple depths. Moreover, there were very few human skeletal remains excavated from the rockshelter, indicating that it was not 
primarily used as a location for the interment of the dead (see Bonor and Martínez Klemm, 1995; Prufer, 2002; Wrobel and Tyler, 2006; Wrobel et al., 2007 for mortuary rockshelters).

Although evidence indicates most, if not all, tool production and use originally occurred outside DVR1, we believe these activities occurred relatively close to the rockshelter. Hayden and Cannon (1983, Fig. 16) observed that the modern Maya spend minimal time and effort in disposing of trash, and that $82 \%$ of waste material is discarded within their compound or within a minute's walk from their houses. Similarly, Deal and Hayden (1987) noted that disposal of sharp glass fragments or implements by modern highland Maya typically occurred close to areas of habitation. Clark (1991) made similar observations concerning the disposal of flaking debris by the Lacandon Maya, who dumped their flaking waste into trash piles not very distant from their homes. However, given the ritual or votive nature of artifact deposition in the rockshelter, pilgrimage to this location from distances farther away cannot be completely discounted (Adams and Brady, 2005; Patel, 2005).

The use-wear on the debitage is similar to that associated with subsistence and domestic activities at surface sites (Lewenstein, 1987; Sievert, 1992, p. 30, Table 4.1; Stemp, 2001; Stemp et al., 2010). We therefore believe that most tool use first occurred outside the rockshelter, in association with basic subsistence and domestic tasks. However, we cannot completely rule out the possibility that some of this use-wear may be the product of ritual activity that occurred within the rockshelter itself.

A comparison among available lithic data from the Deep Valley Rockshelter, the Caves Branch Rockshelter, the Sibun rockshelters, and those from the Maya Mountains indicate minimal variation in their respective chipped stone assemblages, while some important similarities, such as debitage, broken tools, and few imports, have been noted. Any significant variations in assemblage composition do not appear to be due to primary tool-using activities occurring within the rockshelters. Instead, variation of assemblage composition and use-wear patterns is most likely a result of where the debitage was originally produced and used at surface sites prior to secondary deposition in the rockshelters.

It may be that rockshelters in the same valley or region represent a ritual circuit with locations visited at different times and possibly for different reasons. Although this is hard to substantiate archaeologically, one indicator might be the successful refitting of debitage and tools recovered from different rockshelters, which would link these spatially distinct places through a shared sequence of lithic reduction (see Close, 1996). Similarly, a recent study of the much smaller Overlook Rockshelter near DVR1 interpreted the thorough mixing of the ceramic assemblage and lack of sherd refits as likely resulting from the ritual deposition of individual fragments from complete vessels as part of a ritual circuit (Wrobel et al., 2013). Clearly, further research involving stone tools from caves and rockshelters is required to better understand the relationships between lithic artifacts and these locations; this is especially true when contextual difficulties are encountered.

\section{ACKNOWLEDGMenTS}

We would like to thank many individuals and organizations for their support and assistance. Much gratitude is owed to John Morris, Rafael Guerra, and the Belize Institute of Archaeology, as well as Bryan Haley, David Hayles, Ian Anderson, and all the staff at the Caves Branch Adventure Lodge. We would like to acknowledge support from the Belize Archaeological Research and Education Foundation, the University of Mississippi's Office of Research and Sponsored Programs, the Department of Sociology and Anthropology at Ole Miss, and Keene State College's Office of Sponsored Projects and Research. We thank the three anonymous reviewers whose comments and suggestions assisted in improving the clarity and overall quality of the manuscript. Finally, we would like to acknowledge the dedication and hard work of the many students who participated in the 2006 and 2007 CBAS (Caves Branch Archaeological Survey summer fieldschools.

\section{REFERENCES}

Adams, A.E., and Brady, J.E., 2005, Ethnographic notes on Maya Q'eqchi' cave rites: Implications for archaeological interpretation, in Brady, J.E., and Prufer, K.M., eds., In the Maw of the Earth Monster: Mesoamerican Ritual Cave Use: Austin, University of Texas Press, p. $301-327$.

Aldenderfer, M.S., 1991, Functional evidence for lapidary and carpentry craft specialties in the Late Classic of the Central Peten lakes region: Ancient Mesoamerica, v. 2, no. 2, p. 205-214. doi:10.1017/S09565361 00000523.

Andrefsky, Jr., W., 2009, The analysis of stone tool procurement, production and maintenance: Journal of Archaeological Research, v. 17, no. 1, p. 65-103. doi:10.1007/s10814-008-9026-2.

Aoyama, K., 2001, Ritos de plebeyos mayas en la Cueva Gordon no. 3 de Copán (Honduras) durante el periodo Clásico: Análisis de las microhuellas de uso sobre la litica menor de obsidiana: Mayab, v. 14 , p. $5-16$.

Aoyama, K., 2009, Elite Craft Producers, Artists, and Warriors at Aguateca: Lithic Analysis: Salt Lake City, University of Utah Press, Monographs of the Aguateca Archaeological Project First Phase, v. 2, $210 \mathrm{p}$.

Awe, J.J., Griffith, C., and Gibbs, S., 2005, Cave stelae and megalithic monuments in western Belize, in Brady, J.E., and Prufer, K.M., eds., In the Maw of the Earth Monster: Mesoamerican Ritual Cave Use: Austin, University of Texas Press, p. 223-248.

Bassie-Sweet, K., 1991, From the Mouth of the Dark Cave: Commemorative Sculpture of the Late Classic Maya: Norman, University of Oklahoma Press, $287 \mathrm{p}$.

Behm, J.A., 1983, Flake concentrations: Distinguishing between flintworking activity areas and secondary deposits: Lithic Technology, v. 12 , no. 1 , p. $9-16$.

Bonor, J.L., and Martínez Klemm, C., 1995, Trabajos recientes en la región de Caves Branch, Distrito de el Cayo, Belice: V Encuentro Internacional Investigadores de la Cultura Maya, v. 4, p. 250-267.

Brady, J.E., 1989, An investigation of Maya ritual cave use with special reference to Naj Tunich, Petén, Guatemala [Ph.D. thesis]: Los Angeles, University of California, $478 \mathrm{p}$. 
Brady, J.E., and Prufer, K.M., 1999, Caves and crystalmancy: Evidence for the use of crystals in ancient Maya religion: Journal of Anthropological Research, v. 55, no. 1, p. 129-144.

Brady, J.E., and Prufer, K.M., eds., 2005, In the Maw of the Earth Monster: Mesoamerican Ritual Cave Use: Austin, University of Texas Press, 438 p.

Braswell, G.E., Clark, J.E., Aoyama, K., McKillop, H.I., and Glascock, M.D., 2000, Determining the geological provenance of obsidian artifacts from the Maya region: A test of the efficacy of visual sourcing: Latin American Antiquity, v. 11, no. 3, p. 269-282.

Brown, L.A., 2000, From discard to divination: Demarcating the sacred through the collection and curation of discarded objects: Latin American Antiquity, v. 11, no. 4, p. 319-334.

Chase, D.Z., and Chase, A.F., 1996, Maya multiples: Individuals, entries, and tombs in structure A34 of Caracol, Belize: Latin American Antiquity, v. 7, no. 1, p. 61-79.

Chiarulli, B., and Barrick, S., 1997, Analysis of lithic material associated with Tomb 1 from Chau Hiix: Society for American Archaeology Conference, 62nd Annual Meeting, Nashville, Tennessee, Abstracts, $38 \mathrm{p}$.

Clark, J.E., 1991, Modern Lacandon lithic technology and blade workshops, in Hester, T.R., and Shafer, H.J., eds., Maya Stone Tools: Selected Papers from the Second Maya Lithic Conference: Madison, Prehistory Press, Monographs in World Archaeology No.1, p. 251-265.

Close, A.E., 1996, Carry that weight: The use and transportation of stone tools: Current Anthropology, v. 37, no. 3, p. 545-553.

Deal, M., and Hayden, B., 1987, The persistence of pre-Columbian lithic technology in the form of glassworking, in Hayden, B., ed., Lithic Studies among the Contemporary Highland Maya: Tucson, University of Arizona Press, p. 235-331.

Ferguson, J., and Gibbs, S.A., 1999, Report on the 1998 excavations at Actun Uayazba Kab, Roaring Creek Valley, Belize, in Awe, J.J., and Lee, D.F., eds., The Western Belize Regional Cave Project: A Report of the 1998 Field Season: Durham, Occasional Paper No. 2, Department of Anthropology, University of New Hampshire, p. $112-145$.

Flannery, K.V., 1986, Guilá Naquitz: Archaic Foraging and Early Agriculture in Oaxaca, Mexico: Orlando, Academic Press, Studies is Archaeology, $538 \mathrm{p}$.

Freidel, D., Schele, L., and Parker, J., 1993, Maya Cosmos: Three Thousand Years on the Shaman's Path: New York, William Morrow, $543 \mathrm{p}$.

Gibbs, S.A., 1998, Human skeletal remains from Actun Tunichil Muknal and Actun Uayazba Kab, in Awe, J.J., ed., The Western Belize Regional Cave Project: A Report of the 1997 Field Season: Durham, Occasional Paper No. 1, Department of Anthropology, University of New Hampshire, p. 71-95.

Gifford, J.C., 1976, Prehistoric Pottery Analysis and the Ceramics of Barton Ramie in the Belize Valley: Cambridge, Harvard University Press, Memoirs of the Peabody Museum of Archaeology and Ethnology, v. 18, $359 \mathrm{p}$.

Girard, R., 1962, Los Mayas Eternos: Mexico City, Antigua Librería Robredo, $493 \mathrm{p}$.

Graham, E., McNatt, L., and Gutchen, M.A., 1980, Excavations at Footprint Cave, Caves Branch, Belize: Journal of Field Archaeology, v. 7, no. 2, p. 153-172.

Griffith, C.S., 1998, Excavations and salvage operations in Actun Tunichil Muknal and Actun Uayazba Kab, Roaring Creek Valley, Belize, in Awe, J.J., ed., The Western Belize Regional Cave Project: A Report of the 1997 Field Season: Durham, Occasional Paper No. 1, Department of Anthropology, University of New Hampshire, p. 39-69.

Hall, G.D., 1989, Realm of death: Royal mortuary customs and polity interaction in the Classic Maya lowlands [Ph.D. thesis]: Cambridge, Harvard University, $385 \mathrm{p}$.

Halperin, C.T., Garza, S., Prufer, K.M., and Brady, J.E., 2003, Caves and ancient Maya ritual use of jute: Latin American Antiquity, v. 14 no. 2 , p. $207-219$.

Hardy, J., 2009, Understanding functional and symbolic variation in rockshelters of the Caves Branch River Valley of Western Belize, Central America [M.A. thesis]: Oxford, University of Mississippi, $172 \mathrm{p}$.
Hayden, B., and Cannon, A., 1983, Where the garbage goes: Refuse disposal in the Maya Highlands: Journal of Anthropological Archaeology, v. 2, no. 2, p. 117-163. doi:10.1016/0278-4165(83)90010-7.

Healy, P.F., Emery, K., and Wright, L.E., 1990, Ancient and modern Maya exploitation of the jute snail (Pachychilus): Latin American Antiquity, v. 1, no. 2, p. 170-183.

Helmke, C.G.B., 2009, Ancient Maya cave usage as attested in the glyphic corpus of the Maya lowlands and the caves of the Roaring Creek Valley, Belize [Ph.D. thesis]: London, Institute of Archaeology, University College, $697 \mathrm{p}$.

Ishihara, R., 2008, Rising clouds, blowing winds: Late Classic Maya rain rituals in the Main Chasm, Aguateca, Guatemala: World Archaeology, v. 40, no. 2, p. 169-189. doi:10.1080/00438240802030001.

Kavountzis, E.G., 2009, Evaluating cave use through spatial analysis of animal remains from Maya caves in Guatemala and Belize [M.A. thesis]: Gainesville, University of Florida, 219 p.

Keeley, L.H., 1980, Experimental Determination of Stone Tool Uses: A Microwear Analysis: Chicago, University of Chicago Press, Prehistoric Archeology and Ecology series, $212 \mathrm{p}$.

Lewenstein, S.M., 1987, Stone Tool Use at Cerros: The Ethnoarchaeological Use-Wear Analysis: Austin, University of Texas Press, 228 p.

McAnany, P.A., and Peterson, P.A., 2004, Tools of the trade: Acquisition, use, and recycling of chipped stone, in McAnany, P.A., ed., K'axob: Ritual, Work, and Family in an Ancient Maya Village, Monograph 22: Los Angeles, Cotsen Institute of Archaeology, University of California, p. 279-305.

MacLeod, B., and Puleston, D.E., 1978, Pathways into darkness: The search for the road to Xibalba, in Robertson, M.G., and Jeffers, D.C., eds., Tercera Mesa Redonda de Palenque, v. 4: Monterey, Herald Peters, p. 71-77.

McNatt, L., 1996, Cave archaeology of Belize: Journal of Cave and Karst Studies, v. 58 , no. 2, p. 81-99.

Michael, A.R., and Burbank, J.A., 2013, Excavations at Sapodilla Rockshelter, Caves Branch River Valley, in Wrobel, G.D., Morton, S.G., and Andres, C.R., eds., The Central Belize Archaeological Survey Project: A Report of the 2011 Field Season: East Lansing, Michigan, Belize Archaeological Research and Education Foundation, Occasional Report, no. 3, p. 20-37.

Moholy-Nagy, H., 1990, Misidentification of Mesoamerican lithic workshops: Latin American Antiquity, v. 1, no. 3, p. 268-279.

Moholy-Nagy, H., 1997, Middens, construction fill, and offerings: Evidence for the organization of Classic period craft production at Tikal, Guatemala: Journal of Field Archaeology, v. 24, no. 3, p. 293-313.

Morehart, C.T., 2005, Plants and caves in ancient Maya society, in Prufer, K.M., and Brady, J.E., eds., Stone Houses and Earth Lords: Maya Religion in the Cave Context: Boulder, University Press of Colorado, p. $167-185$.

Morrow, T.M., 1996, Lithic refitting and archaeological site formation processes: A case study from the Twin Ditch site, Greene County, Illinois, in Odell, G.H., ed., Stone Tools: Theoretical Insights into Human Prehistory: New York, Plenum Press, Interdisciplinary Contributions to Archaeology series, p. 345-376.

Moyes, H., Awe, J.J., Brook, G.A., and Webster, J.W., 2009, The ancient Maya drought cult: Late Classic cave use in Belize: Latin American Antiquity, v. 20, no. 1, p. 175-206.

Patel, S., 2005, Pilgrimage and caves on Cozumel, in Prufer, K.M., and Brady, J.E., eds., Stone Houses and Earth Lords: Maya Religion in the Cave Context: Boulder, University of Colorado Press, p. 91112 .

Pendergast, D.M., 1971, Excavations at Eduardo Quiroz Cave, British Honduras (Belize): Toronto, Royal Ontario Museum, Art and Archaeology Occasional Paper No. 21, 123 p.

Pendergast, D.M., 1974, Excavations at Actun Polbilche, Belize: Toronto, Royal Ontario Museum, Archaeology Monograph No. 1, 103 p.

Peterson, P.A., 2006, Ancient Maya ritual cave use in the Sibun Valley, Belize [Ph.D. thesis]: Boston, Boston University, 339 p. Reprinted 2006 as Austin, Association for Mexican Cave Studies, Bulletin 16, $148 \mathrm{p}$.

Pohl, M., 1983, Maya ritual faunas: Vertebrate remains from burials, caches, caves, and cenotes in the Maya lowlands, in Leventhal, R.M., and Kolata, A.L., eds., Civilization in the Ancient Americas: Essays in Honor of Gordon R. Willey: Albuquerque, University of New Mexico Press, p. 55-103. 
Prufer, K.M., 2002, Communities, caves, and ritual specialists: A study of sacred spaces in the Maya Mountains of Southern Belize [Ph.D. thesis]: Carbondale, Southern Illinois University, $755 \mathrm{p}$.

Prufer, K.M., 2005, Shamans, caves, and the roles of ritual specialists in Maya society, in Brady, J.E., and Prufer, K.M., eds., In the Maw of the Earth Monster: Mesoamerican Ritual Cave Use: Austin, University of Texas Press, p. 186-222.

Prufer, K.M., and Brady, J.E., eds., 2005, Stone Houses and Earth Lords: Maya Religion in the Cave Context: Boulder, University of Colorado Press, $392 \mathrm{p}$.

Prufer, K.M., and Hurst, W.J., 2007, Chocolate and the underworld space of death: Cacao seeds from an Early Classic mortuary cave: Ethnohistory, v. 54, no. 2, p. 273-301. doi:10.1215/00141801-2006-063.

Prufer, K.M., Wanyerka, P., and Shah, M., 2003, Wooden figurines, scepters, and religious specialists in pre-Columbian Maya society: Ancient Mesoamerica, v. 14, no. 2, p. 219-236. doi:10.1017/S095653 6103142022 .

Rissolo, D., 2003, Ancient Maya Cave Use in the Yalahau Region, Northern Quintana Roo, Mexico: Austin, Association for Mexican Cave Studies, Bulletin 12, 151 p.

Scheffler, T.E., 2008, The El Gigante Rock Shelter, Honduras [Ph.D. thesis]: University Park, The Pennsylvania State University, 434 p.

Sharon, D., ed., 2003, Mesas and Cosmologies in Mesoamerica: San Diego, San Diego Museum of Man, Museum Papers 42, 148 p.

Shelton, R., 2013, A contextual analysis of ceramics from the 2011 excavations of Sapodilla Rockshelter, Caves Branch River Valley, in Wrobel, G.D., Morton, S.G., and Andres, C.R., eds., The Central Belize Archaeological Survey Project: A Report of the 2011 Field Season: East Lansing, Belize Archaeological Research and Education Foundation, Occasional Report, no. 3, p. 38-51.

Sievert, A.K., 1992, Maya Ceremonial Specialization: Lithic Tools from the Sacred Cenote at Chichén Itzá, Yucatán: Madison, Prehistory Press, Monographs in World Archaeology 12, $162 \mathrm{p}$.

Stemp, W.J., 2001, Chipped Stone Tool Use in the Maya Coastal Economies of Marco Gonzalez and San Pedro, Ambergris Caye, Belize: Oxford, British Archaeological Reports International Series 935, 307 p.

Stemp, W.J., 2009, From a land down under: Stone tools from Maya caves in Belize: Maya at the Playa Conference, $3^{\text {rd }}$ Annual Meeting, Palm Coast, Florida, Abstracts, 15 p.

Stemp, W.J., and Awe, J.J., 2014, Ritual use of obsidian from Maya caves in Belize: A functional and symbolic analysis, in Levine, M.N., and Carballo, D.M., eds., Obsidian Reflections: Symbolic Dimensions of Obsidian in Mesoamerica: Boulder, University Press of Colorado, p. 223-254.

Stemp, W.J., Helmke, C.G.B., and Awe, J.J., 2010, Evidence for Maya household subsistence and domestic activities: Use-wear analysis of the chipped chert assemblage from Pook's Hill, Belize: Journal of Field Archaeology, v. 35, no. 2, p. 217-234. doi:10.1179/009346910X 12707321520558.

Stemp, W.J., Wrobel, G.D., Awe, J.J., and Payeur, K., 2013, Stir it up, little darlin': The chipped stone assemblage from mixed deposits from
Caves Branch Rockshelter, Belize: Canadian Journal of Archaeology, v. 37 , no. 1 , p. $123-167$.

Tozzer, A.M., 1941, Landa's Relación de las Cosas de Yucatán: A translation: Cambridge, Papers of the Peabody Museum of American Archaeology and Ethnology, v. 18, 394 p.

Vogt, E.Z., and Stuart, D., 2005, Some notes on ritual caves among ancient and modern Maya, in Brady, J.E., and Prufer, K.M., eds., In the Maw of the Earth Monster: Studies of Mesoamerican Ritual Cave Use: Austin, University of Texas Press, p. 155-185.

Walker, W.H., 1995, Ceremonial trash?, in Skibo, J.M., Walker, W.H., and Nielsen, A.E., eds., Expanding Archaeology: Salt Lake City, University of Utah Press, Foundations of Archaeological Inquiry series, p. 67-79.

Wilson, D.C., 1994, Identification and assessment of secondary refuse aggregates: Journal of Archaeological Method and Theory, v. 1, no. 1, p. 41-68. doi:10.1007/BF02229423.

Wisdom, C., 1940, Chorti Indians of Guatemala: Chicago, University of Chicago Press, Publications in Anthropology, Ethnological Series, $490 \mathrm{p}$

Wrobel, G.D., 2008, Report on the Caves Branch Rockshelter excavations: 2006 and 2007 field seasons, in Helmke, C.G.B., and Awe, J.J., eds., The Belize Valley Archaeological Reconnaissance Project: A Report of the 2007 Field Season: Belmopan, Institute of Archaeology, National Institute of Culture and History, p. 1-19.

Wrobel, G.D., Morton, S., and Andres, C.R., 2010, An introduction to the first season of the Caves Branch Archaeological Survey, in Morris, J., Jones, S., Awe, J., Thompson, G., and Badillo, M., eds., Archaeological Investigations in the Eastern Maya Lowlands: Papers of the 2009 Belize Archaeology Symposium: Belmopan, Institute of Arhaeology, Research Reports in Belizean Archaeology, v. 7, p. 73-84.

Wrobel, G.D., and Shelton, R., 2011, Preliminary salvage operations at Sapodilla Rockshelter, in Andres, C.R., and Wrobel, G.D., eds., Report on the Caves Branch Archaeological Survey Project, Summer 2010 Field Season: Oxford, Mississippi, Belize Archaeological Research and Education Foundation, Occasional Report, no. 2, p. 18-40.

Wrobel, G.D., Shelton, R., Morton, S.G., Lynch, J., and Andres, C., 2013, The view of Maya cave ritual from Overlook Rockshelter, Caves Branch River Valley, Central Belize: Journal of Cave and Karst Studies, v. 75, no. 2, p. 126-135. doi:10.4311/2011AN0233.

Wrobel, G.D., and Tyler, J.C., 2006, Revisiting Caves Branch Rockshelter: Results of the 2005 excavations, in Helmke, C.G.B., and Awe, J.J., eds., The Belize Valley Archaeological Reconnaissance Project: A Report of the 2005 Field Season: Belmopan, Institute of Archaeology, National Institute of Culture and History, p. 1-10.

Wrobel, G.D., Tyler, J., Hardy, J., 2007, Rockshelter excavations in the Caves Branch River Valley, in Morris, J., Jones, S., Awe, J., and Helmke, C., 2007, Archaeological Investigations in the Eastern Maya Lowlands: Papers of the 2007 Belize Archaeology Symposium: Belmopan, Institute of Archaeology, Research Reports in Belizean Archaeology, v. 4, p. 187-196. 